\title{
Pengelolaan Cecingkreman pada Dadia Pasek Gelgel Tabang Desa Bebetin
}

\author{
Luh Weda Laksmi Purnama*, Anantawikrama Tungga Atmadja \\ Universitas Pendidikan Ganesha, Singaraja, Bali, Indonesia \\ *luhwedalaksmipurnama@gmail.com
}

\author{
Riwayat Artikel: \\ Tanggal diajukan: \\ 5 Mei 2020 \\ Tanggal diterima: \\ 22 Mei 2020 \\ Tanggal dipublikasi: \\ 31 Agustus 2020
}

\begin{abstract}
Abstrak
Penelitian ini bertujuan untuk mengetahui (1) latar belakang dibentuknya cecingkreman pada Dadia Pasek Gelgel Tabang Desa Bebetin, dan (2) mekanisme sistem pengelolaan cecingkreman yang ada pada Dadia Pasek Gelgel Tabang Desa Bebetin. Penelitian ini menggunakan penelitian kualitatif dengan jenis penelitian ethnography. Teknik pengumpulan data dilakukan dengan melakukan observasi, wawancara dan juga studi dokumentasi. Objek dari penelitian ini yaitu pengelolaan cecingkreman pada Dadia Pasek Gelgel Tabang Desa Bebetin. Hasil penelitian ini menunjukan bahwa 1) Latar belakangnya terbentuk cecingkreman sebagai sarana untuk membantu krama Dadia Pasek Gelgel Tabang dalam memenuhi kebutuhan yang dimiliki dan juga sebagai sarana untuk menjaga solidaritas yang ada di krama Dadia Pasek Gelgel Tabang Desa Bebetin, 2) Mekanisme sistem pengelolaan cecingkreman yang ada di Dadia Pasek Gelgel Tabang Desa Bebetin dilakukan dengan empat tahap yaitu tahap perencanaan, pelaksanaan, penatausahaan, dan juga pertanggungjawaban.
\end{abstract}

Kata kunci: Pengelolaan Cecingkreman, Dadia

\section{Pengutipan:}

Purnama, L. W. L., \& Atmadja, A. T. (2020). Pengelolaan Cecingkreman pada Dadia Pasek Gelgel Tabang Desa Bebetin. Jurnal Ilmiah Akuntansi dan Humanika, 10 (2), 103-114

\author{
Keywords: Management, \\ Cecingkreman, Dadia
}

\begin{abstract}
This study aimed to determine: (1) the background of the formation of cecingkreman on Dadia Pasek Gelgel Tabang Desa Bebetin, and (2) the mechanism of the management of cecingkreman systems in Dadia Pasek Gelgel Tabang Desa Bebetin. This study was qualitative research with ethnography type. Data collection techniques were done by conducting observation, interviews, and also study documentation. The object of this research was the management of cecingkreman in Dadia Pasek Gelgel Tabang Desa Bebetin. The result show that (1) the background of the formation of cecingkreman is as a means to help the Dadia Pasek Gelgel Tabang society in fullfiling their needs and also as means to maintain solidarity in Dadia Pasek Gelgel Tabang Desa Bebetin, (2) The mechanism of the cecingkreman management system that is owns by Dadia Pasek Gelgel Tabang Desa Bebetin carried out in four stages namely planning, implementation, administration, and also accountability
\end{abstract}

\section{Pendahuluan}

Dadia seperti yang telah kita ketahui merupakan kelompok terkecil dari yang namanya Kawitan. Sehingga dapat dijelaskan bahwa dadia itu merupakan suatu kelompok masyarakat yang berasal dari klan kecil patrilineal yang memiliki hubungan keterikatan satu sama lain melalui garis keturunana laki-laki. Dadia sebagai wadah yang digunakan masyarakat hindu bali yang ada di setiap desa pekraman untuk memuja ataupun menghormati roh para leluhur mereka (Krina, 2003). Salah satu dadia yang ada di Pulau Bali adalah Dadia Pasek Gelgel Tabang Desa Bebetin yang terletak di Kecamatan Sawan 
Kabupaten Buleleng. Dadia merupakan organisasi yang sifatnya non formal dan juga bukan merupakan lembaga keuangan namun dalam hal ini dadia Pasek Gelgel Tabang Desa Bebetin memberikan pinjaman kepada masyarakatnya hanya berlandaskan rasa kepercayaan saja dan juga prosedur peminjaman yang ada di dadia sifatnya sangatlah sederhana.

Pemberian pinjaman kepada krama (masyarakat) dadia lebih dikenal dengan istilah cecingkreman. Cecingkreman merupakan istilah yang diambil dari Bahasa Bali Alus sebagai suatu bentuk pinjaman dana, sehingga dapat disimpulkan bahwa cecingkreman merupakan bantuan dana atau pemberian pinjaman kepada masyarakat dadia yang memerlukan dana. Cecingkreman salah satu kegiatan yang masih eksis dari tahun 1998 hingga saat ini di kalangan masyarakat Dadia Pasek Gelgel Tabang Desa Bebetin seperti yang diungkapkan langsung oleh Sekertaris Dadia Pasek Gelgel Tabang Desa Bebetin Ketut Guna :

"Pemberian kredit di dadia Pasek Gelgel Tabang niki yang kita istilahkan dengan cecingkreman sudah berjaalan dari tahun 1998 hingga saat ini dik"

Dalam peminjaman kredit di Dadia melalui cecingkreman umat tidak perlu menyerahkan jaminanan kredit kepada para pengelola dana. Yang umumnya jaminan kredit merupakan hal yang penting apabila dipertengahan peminjaman para debitur tidak mampu membayar lagi kreditnya, karena pemberian kredit merupakan sesuatu hal yang sangat memiliki resiko tinggi sehingga perlu diperhatikan prinsip-prinsip kredit yang sehat. Namun dalam pelaksanaannya selama ini salah satu dadia yang telah memberikan pinjaman kredit kepada masyarakat dadia melalui Cecingkreman yaitu Dadia Pasek Gelgel Tabang Desa Bebetin belum pernah menemui permasalaan yang sering ditemui oleh Lembaga Pemberi Pinjaman salah satunya yaitu adanya kredit macet.

Umumnya pemberian kredit dilakukan oleh Lembaga Keuangan formal seperti Bank. Bank memiliki satu kegiatan yang menyalurkan dananya ke pihak lain dalam bentuk kredit, biasanya kredit adalah aktiva produktif yang memiliki peran dalam memberikan pendapatan yang paling besar dibandingkan aktiva produktif lainnya. Menurut Undang-Undang No.10 Tahun 1998 tentang Perbankan, Kredit merupakan penyediaan uang atau tagihan yang dapat dipersamakan dengan itu berdasarkan persetujuan atau kesepakatan pinjam meminjam antara bank dan pihak lain yang mewajibkan pihak peminjam untuk melunasi utangnya setelah jangka waktu tertentu dengan pemberian bunga. Setiap Bank yang ada memiliki prosedur pemberian kredit yang berbeda-beda sesuai dengan ketentuan yang ditetapkan di Bank tersebut. Umumnya prosedur perkreditan dimulai dari dilakukanya permohonan kredit oleh nasabah yang mana dalam hal ini nasabah datang ke Bank bersangkutan untuk melakukan permohonan kredit selanjutnya setelah melakukan permohonana kredit akan dilakukan Investigasi Kredit oleh Bank dimana bank akan melakukan pengecekan data-data calon debiturnya. Setelahnya dilakukan Analisis kredit, Bank melakukan analisis ini untuk mengecek dengan mengunjungi tempat jaminan tambahan yang nantinya akan dibuatkan laporan tertulis dalam tahap ini pula Bank menerapkan Formula $5 \mathrm{C}$ dan juga $5 \mathrm{P}$ dan juga dalam analisis kredit, bank juga melakukan analisis keuangan serta analisis rasio. Apabila analisis kredit telah usai dilakukan maka langkah selanjutnya Bank akan mengambil kesmpulan dan juga keputusan apakah calon debitur tersebut layak untuk diberi kredit atau tidak.

Penelitian sejenis pernah dilakukan oleh (Nurdamasih, 2019) yang mengangkat judul "Transparansi dan Akuntabilitas Pengelolaan Keuangan Sistem Pemberian Kredit Mutranin Pada Dadia Tangkas Kori Agung Desa Pekraman Bila Bajang, Kecamatan Kubutambahan". Dalam penelitian yang dilakukan oleh Nurdamasih, meneliti mengenai pengelolaan keuangan dari adanya sistem mutranin yang diterapkan di desa Bila Bajang Kecamatan Kubutambahan utamanya mengenai Transparansi dan juga Akuntabilitas dari pengelolaan keuangannya. Hasil penelitian (Nurdamasih, 2019) menunjukan bahwa: (1) Pengelolaan keuangan sistem mutranin dilakukan melalui empat tahapan yakni perencanaan, pelaksnaan, penatausahaan, san pertanggungjawaban. (2) Penerapan prinsip transparansi dan akuntabilitas dalam proses pengelolaan keuangan sistem mutranin sudah dilakukan 
dengan baik. (3) Kendala yang dihadapi yakni adanya krama yang menunggak, yang disebabkan karena ketiadaan awig-awig serta sanksi dan krama yang enggan menghadiri sangkepan.

Sementara pada penelitian ini akan diteliti lebih jauh mengenai latar belakang yang membentuk dijalankan cecingkreman dan juga mekanisme sistem pengelolaan cecingkreman yang ada Dadia Pasek Gelgel Tabang Desa Bebetin. Sehingga dengan telah dilakukan penelitian sebelumnya oleh (Nurdamasih, 2019) peneliti tertarik untuk mengulik lebih jauh mengenai Pengelolaan Cecingkreman Pada Dadia Pasek Gelgel Tabang dan yang menjadi alasan dilakukan penelitian ini antara lain sebagai berikut: (1) Pemberian kredit melalui cecingkreman ini bersifat sangat sederhana dengan tidak menggunakan prosedur ataupun prinsip umum yang telah diterapkan oleh bank. (2) Dadia Pasek Gelgel Tabang merupakan salah satu dadia terbesar kedua yang ada di lingkungan Desa Bebetin dan juga dadia ini memiliki jumlah asset yang cukup besar yaitu sebesar Rp 46.365 .000 yang semuanya beredar di masyarakat dadia yang meminjam sehingga kas yang ada di dadia kosong, dan juga memberikan pemberian kredit kepada masyarakatnya tanpa memberikan jaminan apapun sehingga peneliti tertarik untuk mengetahui tentang pengelolaan cecingkreman yang ada di dadia Pasek Gelgel Tabang Desa Bebetin (3) Pelaksanaan dana cecingkreman yang ada di Dadia Pasek Gelgel yang sudah berjalan hampir 21 tahun mulai tahun 1998 hingga saat ini dan belum pernah terjadi masalah, namun pada penelitian (Nurdamasih, 2019) menyebutkan bahwa di lokasi tempatnya melakukan penelitian terdapat kurang lebih Rp. 100.000 .000 kredit yang mangkrak pembayarannya bahkan bunga pokok saja tidak dibayar. Sehingga hal ini membuat peneliti ingin mengetahui apa yang mendasari krama yang meminjam dana cecingkreman ini selalu menunaikan kewajiban pinjamannya.

Berdasarkan pemamaparan diatas adapun rumusan masalah yang akan dibahas yaitu: (1) Bagaimana latar belakang dibentuknya cecingkreman pada Dadia Pasek Gelgel Tabang Desa Bebetin, dan (2) Bagaimana mekanisme pengelolaan cecingkreman pada Dadia Pasek gelgel Tabang Desa Bebetin.

\section{Metode}

Penelitian ini menggunakan metode kualitatif dengan jenis penelitian ethnography yang merupakan jenis penelitian yang melakukan studi ataupun pengamatan tehadap budaya dari suatu kelompok dalam kondisi alamiah melaui observasi dan wawancara (Creswell, 2012) dalam (metode penelitian kuantitatif, kualitatif,dan R\&D, 2016). Penelitian ini dilakukan di Dadia Pasek Gelgel Tabang Desa Bebetin dan yang menjadi objek penelitian yaitu mengenai Pengelolaan Cecingkreman yang ada Dadia Pasek Gelgel Tabang Desa Bebetin. Jenis data yang digunakan dalam penelitian ini yaitu data kualitatif dan sumber data berasal dari hasil wawancara, aktivitas observasi, dan juga studi dokumentasi. Subjek dalam penelitian kali ini yaitu pihak-pihak yang mengetahui mengenai pengelolaan cecingkrem seperti Kelian, Sekertaris, Bendahara dan juga masyarakat Dadia Pasek Gelgel Tabang Desa Bebetin. Pengumpulan data dilakukan dengan tiga teknik yaitu teknik wawancara, observasi dan studi dokumentasi. Selanjutnya data yang telah diperoleh dianalisis dengan reduksi data, penyajian data, analisis data dan penarikan kesimpulan.

\section{Hasil dan Pembahasan}

\section{Latar Belakang Dibentuknya Ceceingkreman}

Cecingkreman merupakan istilah yang digunakan oleh Dadia Pasek Gelgel Tabang Desa Bebetin dalam memberikan pinjaman dana bagi masyarakat dadia yang memerlukan dana. Istilah cecingkreman yang digunakan oleh Dadia Pasek Gelgel Tabang Desa Bebetin ini diambil dari Bahasa Bali Alus, dan juga cecingkreman yang ada sudah ada dari tahun 1998 hingga saat ini dan sudah berjalan selama 21 tahun. Hal ini disampaikan langsung oleh Sekertaris Dadia Pasek Gelgel Tabang Desa Bebetin Ketut Guna dari hasil wawancara yang telah dilakukan sebagai berikut:

"Jadi begini nak kalau ditelaah dalam Bahasa Bali Alus itu cecingkreman merupakan istilah yang lebih halus digunakan untuk memberikan pinjaman, 
banyak sebenarnya bahasa yang bisa digunakan, di tempat lain banyak yang menggunakan istilah mutranin, yang mana hal niki sebenernya sama, namun cecingkreman itu lebih halus, dan juga cecingkreman yang ada di dadia kami ini sudah berjalan selama 21 tahun namun penetapan nama cecingkreman baru 3 tahun yang lalu setelah ditetapkan adanya awig-awig baru"

\section{Kebutuhan Manusia Akan Uang}

Cecingkreman yang ada di dadia Pasek Gelgel Tabang ini dibentuk untuk memberikan manfaat tersendiri baik bagi krama yang ada di Dadia tersebut ataupun bagi Dadia itu sendiri. Rochmawan (2008:4) dalam jurnal (Gunawijaya, 2017) menyebutkan bahwa kebutuhan manusia itu sangat banyak dan juga beraneka ragam yang setiap harinya akan selalu bertambah dan tidak akan ada habisnya yang mana hal ini sejalan dengan adanya perkembangan mengenai kemajuan ilmu pengetahuan dan juga teknologi. Hal ini senada dengan apa yang diungkapakan oleh Kelian Dadia Pasek Gelgel Tabang Desa Bebetin I Made Suparjo berdasarkan hasil wawancara:

"Cecingkreman niki merupakan pinjaman yang diberikan kepada masyarakat dadia kami yang memerlukan dana, karena selaku pengelola kami mengetahui masyarakat dadia kami tidak semuanya bisa memenuhi kebutuhan hidupnya dengan uang mereka, karena terkadang ada saja keperluan mendadak yang memerlukan dana lebih sehingga kami menyediakan itu demi kesejahteraan masyarakat kami dan juga membantu memenuhi kebutuhan hidup yang dimilikinya"

Sehingga apa yang disampaikan oleh pengelola Dadia Pasek Gelgel diatas senada dengan apa yang diungkpakan (Mankiw, 2007) bahwa dalam upaya memenuhi kebutuhan hidup yang dimiliki oleh setiap manusia maka manusia memerlukan uang, karena uang merupakan sarana transaksi yang dianggap sah. Prilaku berhutang menjadi suatu yang lumrah dikalangan masyarakat hal ini terjadi karena pilihan prilaku ekonomi masyarakat sebagai sarana untuk memenuhi kebutuhan hidup yang dimiliki. (Shohib, 2013) menyebutkan bahwa prilaku berutang mulai timbul disaat adanya kebutuhan yang menuntut adanya persediaan uang yang melebihi dari jumlah pendapatan yang dimiliki. Umumnya masyarakat yang ingin meminjam uang akan pergi ke Badan Lembaga Keuangan formal baik itu Bank ataupun Lembaga Pemberi Kredit untuk meminjam uang. Dalam melakukan pemberian kredit Bank sangat memperhatikan prinsip-prinsip pemberian kredit yang sehat yaitu $6 \mathrm{C}$ dan 7 P. Namun dalam hal ini dadia memberikan pinjaman kepada masyarakat dadia melalui cecingkreman, dengan menggunakan prosedur ataupun mekanisme peminjaman yang sangat sederhana. Hal ini disampaikan oleh Bendahara Dadia Pasek Gelgel Tabang Desa Bebetin Bapak Nyoman Sarjana dari hasil wawancara yang telah dilakukan sebagai berikut:

"Di dadia kami memang benar adanya memberikan pinjaman kepada masayarakat dadia dengan istilah cecingkreman punika (itu), cecingkremanpunika kan pemberian pinjaman kepada masyarakat dadia kami dan kami dalam memberikan cencingkreman tersebut melalui prosedur yang sangat sederhana karena kami tahu bahwa jika meminjam di Bank, koperasi, ataupun LPD prosedur yang diterapkan sangatlah ribet dan sulit sehingga kami disini membantu masyarakat dadia dengan memberikan pinjaman dengan prosedur sederhana dan lebih kekeluargaan"

Sehingga dapat dari pemamparan diatas dapat disimpulkan bahwa cecingkreman ini dibentuk untuk mensejahterakan krama dadia yang ada dengan memberikan pinjaman dana bagi yang memerlukan tanpa harus menggunkan prosedur yang umumnya diterapkan oleh Bank. 


\section{Penggalangan Dana Kolektif}

Dalam memberikan pinjaman melalaui cecingkreman Dadia Pasek Gelgel memperoleh dana dari adanya penggemukan dana di dadia. Penggemukan dana yang ada di dadia Pasek Gelgel Tabang Desa Bebetin ini hampir keseluruhannya berasal dari krama dadia itu sendiri. (Pandu, 2016) menyebutkan bahwa sumber-sumber pemasukan dadia ada 3 jenis diantaranya: Peturunan (Dana Urunan), Dana Punia, Bantuan Sosial. Dana-dana ini umumnya digunakan untuk membiayai seluruh keperluan pura dadia agar bisa melaksanakan upacara untuk pendekatan kepada Tuhan Yang Maha Esa (Pandu, 2016). Hal ini sesuai dengan apa yang disampaikan oleh Kelian Dadia Pasek Gelgel Tabang Desa Bebetin dari hasil wawancara yang dilakukan sebagai berikut:

"Dadia kami ini jumlah KKnya saat ini yaitu sebanyak 200 KK, seperti dadia lainnya yang ada, di dadia kami juga memerlukan dana untuk menjalankan berbagai kegiatan yang ada seperti kegiatan utama di Dadia itu yaitu melaksanakan piodalan sebagai wujud sembah bakti kita kepada Tuhan Yang Maha Esa dan juga leluhur kami di waktu tertentu. Nah dana-dana yang ada di dadia kami yang digunakan untuk membiayai seluruh kegiatan itu berasal dari krama seperti dari dana peturunan yang dipungut dari setiap KK yang terdfatar dan jumlah uang yang akan dikumpulkan didasarkan pada ketentuan yang telah disetuji pada saat pelaksanaan paruman (rapat), lalu ada dana makat kalau dana ini di dapatkan dari uang denda, jadi apabila di dadia kami sedang melaksanakan kegiatan dan ada krama yang tidak menghadiri kegiatan maka kami kenakan makat yang mana tiap kk itu dikenakan Rp. 50.000, ada juga dana punia yang berasal dari masyarakat yang menyumbang secara tulus ikhlas, uang canang sari yang berasal apabila dilakukan persembahyangan dan ada yang menaruh uang diatas canang sari ataupun bantennya dan juga ada dari dana lelang biasanya dana ini di dapatkan dari setelah piodalan apabila ada lungsuran tersebut dilelangkan kepada yang mau"

Sehingga dari teori yang telah disampaikan (Pandu, 2016) dengan apa yang telah disampaikan oleh pengelola Dadia Pasek Gelgel Tabang memiliki kesesuaian bahwa dana yang ada di Dadia Pasek Gelgel itu bersumber dari krama yang ada baik itu dari pengumpulan dana peturnan, punia, makat, ataupun lelang.

Penggemukan dana di dadia bermula pada saat akan dilaksanakan piodalan pura dadia dan terdapat sisa dana yang mana apabila dana tersebut di diamkan akan mengendap begitu saja tidak menghasilkan sesuatu yang berguna baik bagi krama ataupun bagi dadia. Hal ini juga disamapaikan oleh Kelian Dadia Pasek Gelgel Tabang Desa Bebetin Bapak I Made Suparjo:

"Di dadia kami ini kan terdapat dana-dana yang biasanya dikumpulkan dik baik itu pada saat piodalan (persembahyangan) ataupun pada saat akan dilakukan pembangunan pura dan juga dari berbagai sumber dana lainnya yang mana terdapat uang sisa, uang sisa dengan jumlah yang lumayan tersebut apabila kita diamkan begitu saja tidak akan memiliki arti apa-apa dan mungkin bisa jadi wongan (jamuran) uangnya, apalagi seperti yang adik ketahui tingkat inflasi di negara kita semakin melaju tiap tahunnya, dulu jaman bapak kalau dikasi uang seratus ribu sudah bisa membeli banyak sekali barang, sedangkan kalau adik sekarang dikasi uang seratus ribu mungkin cuman bisa dapat beberapa barang, nah dari itu kami memutuskanlah untuk membentuk cecingkreman ini karena manfaatnya juga tidak hanya akan dirasakan oleh dadia namun banyak juga bagi krama dadia (masyarakat)"

Sehingga dapat disimpulkan bahwa penggemukan dana yang dilakukan oleh dadia memiliki tujuan untuk mendanai kegiatan yang ada di dadia itu sendiri seperti mendanai kegiatan piodalan yang dilakukan di pura dadia dan juga sisa dana dari penggemukan 
tersebut disalurkan kembali kepada krama dadia dalam bentuk cecingkreman sebagai upaya membantu krama dadia yang memerlukan dana.

\title{
Menjaga Solidaritas Krama
}

Cecingkreman ini digunakan sebagai wadah untuk melakukan kumpul tiap bulannya (sangkepan). Dalam hal ini para pengelola Dadia Pasek Gelgel Tabang Desa Bebetin menyadari dengan seiringnya kemajuan zaman maka solidaritas ditakutkan akan semakin memudar. Dalam menjalankan kehidupan sehari-harinya manusia akan selalu mebutuhkan satu sama lain. Sehingga interaksi sosial sebgai suatu kunci dari semua kehidupan sosial, apabila tidak ada interaksi sosial maka tidak akan ada kehidupan bersama dan membentuk sebuah organisasi sosial yang tujuannya untuk mewujudkan tujuan. Masyarakat desa merupakan masyarakat yang memiliki ikatan perasaan batin yang kuat antar sesamanya dan juga mempunyai perasaan yang bersedia untuk berkorban setiap waktu demi anggota masyarakatnya (Nasution, 2009) Sehingga dengan adanya ikatan batin satu sama lain dan seringnya terjadi interaksi sosial antar sesama masyarakat membuat solidaritas yang ada dimasyarakat desa itu tinggi. Dari hasil wawancara yang dilakukan dengan Kelian Dadia Pasek Gelgel Tabang Desa Bebetin I Made Suparjo mengatakan bahwa:

\begin{abstract}
"Begini dik awalnya kan cecingkreman ini dibentuk dari ngobrol-ngobrol bersama krama, na pada saat itulah kita membahas bagaiamana cara agar kita dapat berkumpul tiap bulan, seperti yang telah disadari oleh krama, bahwa semakin maju jaman akan semakin susah kita untuk berkumpul karena namanya juga manusia ya dik punya kepentingannya masing-masing, sehingga apabila tidak sering berkumpul kita akan jarang juga berbicara satu sama lain atau dalam bahasa Indonesia bisa dibilang dengan interaksi, dengan jarangnya melakukan interaksi ini kadang kita bisa menjadi orang yang apatis dengan individu lainnya, sosial ataupun lingkungan dik, padahal manusia kan mahluk sosial dan juga apabila krama yang ada di dadia kami ini semuanya menjadi apatis bisa hancur dadia ini, sehingga dari hasil mengobrol bersama krama lainnya kami mengambil jalan lah untuk membentuk cecingkreman ini sebagai sarana kumpul tiap bulannya untuk membahas berbagai hal yang ada di dadia ataupun menampung masukan-masukan dari krama apabila ada dik, sehingga diharapkan dengan dibentuknya cecingkreman ini krama yang ada di dadia kami tidak bersifat apatis dan selalu mengenal satu sama lain sehingga solidaritas yang ada di krama tetap terjaga dan juga mencegah terjadi perpecahan di dadia"
\end{abstract}

Sehingga dapat disimpulkan bahwa pembentukan cecingkreman ini juga memiliki manfaat bagi dadia itu sendiri sebagai sarana untuk menjaga solidaritas antar krama agar tidak terjadinya sikap apatisme dan juga perpecahan antar krama.

\section{Prosedur Pemberian Cecingkreman}

Umumnya bank dalam memberikan kredit akan menerapkan berbagai prosedur dan juga sangat memperhatikan prinsip-prinsip yang ada hal ini dikarenakan penyaluran kredit merupakan sesuatu yang memiliki resiko yang besar. Adapun prosedur pemberian kredit yang sehat pada Bank yaitu dengan memperhatikan prinsip-prinsip pemberian kredit dengan melakukan analisis $6 \mathrm{P}$ dan $7 \mathrm{P}$ serta studi kelayakan, hal ini dilakukan oleh bank sebagai upaya untuk mencegah terjadi kredit macet dikarenakan pemberian kredit merupakan suatu hal yang memiliki resiko tinggi. Namun dalam hal ini Dadia Pasek Gelgel Tabang Desa Bebetin menerapkan prosedur yang sifatnya masih sangat sederhana dan juga analisis pemberian kredit oleh dadia dilakukan secara tidak formal seperti yang diterapkan oleh bank pada umumnya yang mana hal ini dapat ditunjukan dari dilakukannya penyamapaian peminjaman cecingkreman oleh krama dadia. Adapun prosedur peminjaman cecingkreman yang ada di Dadia Pasek Gelgel Tabang Desa Bebetin antara lain adalah sebgai berikut yang dirangkum berdasarkan hasil wawancara yang telah dilakukan dengan Bendahara Dadia Pasek Gelgel Tabang Desa Bebetin Bapak Nyoman Sarjana: 


\begin{abstract}
"Sebenarnya untuk peminjaman ini sifatnya sangat sederhana dik benar-benar sederhana tidak seeperti yang umumnya dilakukan oleh Bank yang adik ketehui sebagai lembaga formal pemberi pinjaman karena memang ini dadia kan bukan bank dik dan juga di dadia itu lebih bersifat kekeluargaan, nah untuk tata cara peminjamannya itu ya begini, pertama tiang akan melakukan perekapan terlebih dahulu dik mengenai berapa jumlah jinah (uang bunga) sane terkumpul pada bulan itu yang nantinya hasil perekapan ini akan tiang umumkan pada saat dilakukan paruman (rapat) tiap bulannya. Tahap kedua ini bisa tiang (saya) katakan sebagai tahap pendaftaran, nah disini krama yang ingin meminjaam itu nanti harus menyampaikan niatannya yaitu meminjam uang pada saat dilakukannya paruman atau sangkepan nah biasanya dik kalau di dadia kami tiang selaku bendahara akan menanyakan kepada seluruh krama pada saat paruman apakah ada yang ingin meminjam cecingkreman atau tidak, setelahnya apabila ada yang ingin meminjam krama wajib mendaftarkan dirinya kepada tiang dan tiang akan mencatat siapa saja krama yang akan meminjam cecingkreman punika. Tahap terakhir yaitu tahap pemberian cecingkreman nike dik, jadi disini tiang akan memberikan cecingkreman yang telah diajukan sebelumnya oleh krama dengan merekap terlebih dahulu berapa jumlah kramasane akan meminjam cecingkreman bulan nike sehingga jumlah krama yang akan meminjam cecingkremannike akan dibagi rata dengan jumlah jinahsane sampun ke kumpul, seperti niki sederhananya dik apabila jinah tersebut terkumpul sebanyak Rp. 2.000.000 dan jumlah kramasane ingin pinjam uang sebanyak 5 orang jadi kita prajuru akan membagi uang Rp. 2.000 .000 nike kepada 5 orang tersebut sehingga mereka akan mendapatkan uang sebesar Rp. 400.000 begitu dik"
\end{abstract}

\title{
Mekanisme Sistem Pengelolaan Cecingkreman
}

Pengelolaan keuangan merupakan suatu hal yang penting yang ada di setiap organisasi. Dengan dilakukannya pengelolaan keuangan secara maksmimal nantinya akan sangat membantu bagi tiap organisasi yang ada baik itu yang sifatnya profit ataupun non profit dalam memperlancar segala kegiatan yang dimiliki oleh tiap organisasi (Megawati, 2014). Menurut pasal 1 Ayat 8 dalam Peraturan Mentri dalam negeri Nomor 21 Tahun 2011 menyebutkan bahwa Pengelolaan Keuangan Daerah merupakan keseluruhan kegiatan yang meliputi perencanaan, pelaksanaaan, penatausahaan, pelaporan, pertanggungjawaban, dan pengawasan keuangan daerah. Dalam menjalankan kegiatan cecingkremaan Dadia Pasek Gelgel Tabang Desa Bebetin juga melaksankanan beberapa tahap-tahap pengelolaan keuangan seperti yang dilakukan oleh Daerah diantaranya sebagai berikut:

\section{Perencanaan Pengelolaan Dana}

Dalam aspek perencaan biasanya akan terangkum perumusan tujuan dan cara mencapai tujuan tersebut dengan memanfaatkan berbagai sumber daya yang ada (Bastian, 2010). Sumber daya yang dimaksudkan bisa berupa uang ataupun manusia. Dadia Pasek Gelgel Tabang Desa Bebetin mememiliki dana yang dikelola yang hampir keseluruhannya berasal dari krama dadia itu sendiri. Hal ini disampaikan oleh Bendahara Dadia Pasek Gelgel Tabang Desa Bebetin Nyoman Sarjana sebagai berikut:

"Di dadia kami untuk sumber dana yang utama memang dari dana peturunan dik, namun ada juga sumber pemasukan lainnya seperti kalau dilaksanakan piodalan di dadia ataupun pada saat hari-hari keagamaan, dadia dapat pemasukan juga dari dana punia, dana makat, atapun dana lelang yang mana nanti semua dana tersebut akan menjadi kas dadia dik" 
Sehingga dapat disimpulkan bahwa dari hasil pemaparan diatas Dadia Pasek Gelgel Tabang Desa Bebetin memiliki sumber pemasukan yang berasal dari peturunan yang dilakukan krama sebagai sumber pemasukan utamanya lalu pemasukan lainnya berasal dari dana punia, dana makat, dan juga dana lelang, yang mana hal ini sejalan dengan apa yang telah disampaikan oleh (Riani, 2017) yang menyebutkan bahwa organisasi keagamaan seperti dadia memiliki 2 jenis sumber pendanaan yaitu yang berasal dari dadia itu sendiri atau disebut juga sumber pendanaan regular dan juga yang berasal dari luar dadia itu yang disebut dengan sumber pendanaan non regular.

Dana yang terkumpul ini apabila didiamkan begitu saja akan tidak memiliki manfat sama sekali atau yang lebih dikenal dengan istilah idle money. Teguh Wahyuno, M.B.A., Aff.W.M mengemukakan bahwa idle money merupakan dana yang tidak produktif sehingga akan tergerus tingkat inflasi tiap tahunnya. Sehingga dengan banyaknya jumlah dana yang terkumpul Dadia Pasek Gelgel Tabang Desa Bebetin ini membuat suatu perencanaan yaitu membentuk cecingkreman yang memiliki tujuan untuk mensejahterakan krama dadia yang ada, sebagai sumber pemasukan dadia, ataupun sebagai wadah untuk menjaga solidaritas krama. Hal ini disampaikan oleh Kelian Dadia Pasek Gelgel Tabang Desa Bebetin I Made Suparjo dari hasil wawancara yang telah dilakukan sebaga berikut:

"Di dadia kami ini kan terdapat dana-dana yang biasanya dikumpulkan dik baik itu pada saat piodalan (persembahyangan) ataupun pada saat akan dilakukan pembangunan pura dan juga dari berbagai sumber dana lainnya yang mana terdapat uang sisa, uang sisa dengan jumlah yang lumayan tersebut apabila kita diamkan begitu saja tidak akan memiliki arti apa-apa dan mungkin bisa jadi wongan (jamuran) uangnya, apalagi seperti yang adik ketahui tingkat inflasi di negara kita semakin melaju tiap tahunnya, dulu jaman bapak kalau dikasi uang seratus ribu sudah bisa membeli banyak sekali barang, sedangkan kalau adik sekarang dikasi uang seratus ribu mungkin cuman bisa dapat beberapa barang, nah dari itu kami memutuskanlah untuk membentuk cecingkreman ini karena manfaatnya juga tidak hanya akan dirasakan oleh dadia namun banyak juga bagi krama dadia (masyarakat)"

\section{Pelaksanaan}

Pengimplementasian dari dilakukannya cecingkreman di Dadia Pasek Gelgel Tabang Desa Bebetin yaitu dengan menentukan jumlah anak jinah (bunga) yang akan dipungut tiap satu bulan bali bagi krama yang meminjam cecingkreman tersebut. Besarannya anak jinah (bunga) yang disepekati tersebut akan menentukan berapa besar jumlah pemusakan yang akan diperoleh dadia dari dilakukannya cecingkreman tersebut. Hal ini sesuai dengan apa yang diutarakan oleh Bendahara Dadia Pasek Gelgel Tabang Desa Bebetin Nyoman Sarjana sebgai berikut:

"Seperti umumnya pemberian pinjaman yang dilakukan, kami juga para pengelola dadia menentukan anak jinah dari peminjaman cecingkreman punika dik, yang mana nantinya anak jinah tersebut akan dipungut tiap satu bulan bali (35 hari) pada saat dilakukan sangkepan ataupun rumah ke rumah dik, untuk besaran anak jinah tersebut kami di dadia sepakat pada saat dilakukannya paruman yaitu anak jinahnya (bunga) sebesar $2 \% "$

Selain menentukan jumlah besarannya anak jinah yang akan dipungut tiap 1 bulan bali, dalam pelaksanaan cecingkreman pengelola perlu membuatkan kebijakan-kebijakan yang nantinya dapat mendukung kesuksesan dari cecingkreman itu sendiri. Hal ini sesuai dengan apa yang telah tercantum dalam awig-awig Dadia Pasek Gelgel Tabang Desa Bebetin Palet 6 Indik Utsaha Krama Dadia Pawos 23 yang berbunyi: 
"Pamargin Utsaha punika patut kaiket atuk daging awig-awig tur uger-uger ring sajeroning cecingkreman. 1. Pamigunan cecingkreman puniki kemargiaang ring sajeroning krama Dadia Pasek Gelgel Tabang, 2. Agung alit jinah sane kaselang olih krama keni bunga manut pararem, 3. Sane kedadosang nyelang jinah wantah krama dadia tur kadulurin atuk lingga tangan krama dadia sane nyelang, 4 yening wenten sinalih tunggil krama daadia pacing nyelang tegak mangda mesadok ring madruwe tegak tur kabuktiyang antuk lingga tangan, 5. Yening wenten sinalih tunggil krama dadia nenten prasida nawur bunga patut kekenin panikel"

Yang artinya:

"Usaha cecingkreman secara keseluruhannya telah diatur dalam awig-awig. 1. Kegunaan cecingkreman ini diberikan kepada krama Dadia Pasek Gelgel tabang Desa Bebetin, 2. Besar kecilnya dan ayang dipinjam dikenakan bunga yang telah disepakati sebelumnya pada saat dilakukan paruman, 3. Yang ingin meminjam uang hanya krama dadia dan yang menandatangani krama dadia yang meminjam, 4. Apabila ada krama yang ingin meminjam kembali boleh meminjam nama krama yang tdiak meminjam dengan berdiskusi telebih dahulu dengan pemilik nama dan harus mendapatkan rekomendasi dari pemilik nama, 5. Apabila ada krama yang ingin meminjam dan krama tersebut tidak membayar bunganya maka harus dikenakan panikel'

\section{Penatausahaan}

Dalam tahap penatausahaan ini akan meliputi kegitan penerimaan dan juga pengeluaran yang didasarkan pada prinsip-prinsip ataupun prosedur-prosedur yang ada sehingga nantinya akan mampu memberikan informasi yang aktual di bidang keuangan. Dalam tahap penatausahaan ini Dadia Pasek Gelgel Tabang Desa Bebetin pencatatan mengenai cecingkreman dibuat dengan secara sederhana yang mana hal ini memiliki tujuan agar pencatatan tersebut juga dimengerti oleh krama dadia yang ada. Hal tersebut disampaikan oleh Bendahara Dadia Pasek Gelgel Tabang Desa Bebetin Nyoman Sarjana:

"Pencatatan mengenai cecingkreman ini tiang lakukan bersama sekertaris dadia dik karena terkadang jika saya tidak bisa memungut pada bulan tersebut uangnya akan dipungut oleh sekertaris dadia dik. Untuk format pencatatan cecingkreman niki kan sudah dibuat dari pertama dilakukannya cecingkreman tahun 98 jadi kami hanya mengikutinya saja dan buku yang kami gunakan pun masih sama dengan buku pada tahun tersebut, kami masih menggunakan tata cara pencatatan tersebut karena menurut kami dan juga krama sangat mudah untuk dimengerti"

Dari dilakukannya kegiatan cecingkreman ini maka dadia akan memperoleh anak jinah yang mana anak jinah ini merupakan bunga dari dana yang dipinjam oleh krama yang mana anak jinah yang terkumpul ini umumnya digunakan untuk membantu pendanaan kegiatan-kegiatan yang ada di dadia seperti pelaksanaan kegiatan piodalan. Dengan dilakukan pencatatan yang sedemikian rupa terkait dengan pengelolaan keuangan cecingkreman mencerminkan adanya kegiatan pengelolaan keuangan yang dilaksanakan secara transaparan dan juga akuntabel dalam pengelolaan keuangan cecingkreman yang ada di Dadia Pasek Gelgel Tabang Desa Bebetin. Dengan dilakukannya pencatatan yang masih sangat sederhana tersebut sangat membantu dalam menjawab dan juga mengantisipasi apabila ada kecurigaankecurigaan yang muncul di krama dadia mengenai kinerja dari prajuru. 


\section{Pertanggungiawaban}

Umumnya pertanggungjawaban yang dilakukan di dadia itu masih sangat sederhana hal ini tentunya dikarenakan memang belum adanya standar ataupun peraturan yang berlaku mengenai pengelolaan keuangan di dadia. Namun pengelola dadia harus tetap membuat pertanggungjawaban mengenai berbagai pengelolaan keuangan yang ada karena dadia merupakan organisasi non formal yang sumber dananya hampir secara keseluruhan berasal dari krama dadia itu sendiri. Dadia Pasek Gelgel Tabang melakukan pertanggungjawaban keuangan setiap kegiatan yang ada yaitu pada saat dilakukanya paruman tepatnya pada wrespati manis ataupun sebelum dilakukannya piodalan di pura dadia yang mana pertanggungjawaban keuangan dilakukan dengan cara menyampaiakan secara mendetail kepada seluruh krama mengenai pengelolaan keuangan yang telah dilakukan oleh para pengelola selanjutnya apabila dari krama ada yang kurang mengerti atas penyampaian para pengelola maka krama dapat secara langsung menanyakan kepada pengelola dadia, dan juga para pengelola akan memperlihatkan kepada krama dadia mengenai laporan pertanggungjawaban yang telah dibuat. Hal ini disampaikan oleh Kelian Dadia Pasek Gelgel Tabang Desa Bebetin Bapak Made Suparjo sebagai berikut :

"Untuk pertanggungjawaban mengenai pengelolaan dana ini kami selaku praju dan krama sudah menyepakati dilakukan setiap Wrespati Manis atau biasanya juga sebelum dilaksanakannya piodalan di Dadia, yang mana nanti bendahara akan mengumumkan mengenai berapa jumlah kas yang terkumpul dari anak jinah pada saat itu berapa jumlah uang yang tersebar dan siapa saja yang meminjam uang, sehingga baik prajuru dan juga krama nantinya akan mengetahui"

Dengan penyampaian tersebut Dadia Pasek Gelgel Tabang telah melakukan prinsip transparansi. Tranparansi menurut (Krina, 2003) merupakan prinsip yang menjamin kebebasan bagi setiap orang untuk memperoleh informasi mengenai penyelenggaraan pemerintah yang terdiri dari informasi tentang kebijakan dan proses pembuatan serta hasil yang dicapai. Oleh karena itu dengan adanya transaparansi akan mampu membangun kepercayaan semua pihak terhadap kinerja pengemban amanah selama menjalankan tugas dan kewajiban yang dimiliki. Hal ini juuga disamapaikan oleh Sekertaris Dadia Pasek Gelgel Tabang Desa bebebtin Ketut Guna sebagai berikut :

"Untuk seluruh masalah mengenai pengelolaan keuangan di dadia kami selaku prajuru sangat terbuka dik. Kami selalu mengumkan mengena jumlah dana yang dimiliki dadia pada saat paruman baik itu pemasukan dan juga pengeluarannya, apalagi untuk cecingkreman ini jumlah uang yang tersebar di krama terbilang cukup besar dan juga jinah yang diperoleh dadia sangat lumayan, sehingga kami selaku pengelola dadia selalu berusaha untuk membangun dan juga menjaga kepercayaan yang telah diberikan kepada kami selaku pengelola dadia dengan memberikan semua informasi mengenai keuangan kepada krama"

Hal senada juga disampaikan oleh krama dadia Pasek Gelgel Tabang Desa Bebetin Bapak Jro Mangku Sabda sebagai berikut:

"Pertanggungjawaban yang dilakukan oleh para prajuru dadia menurut saya sudah transparan, karena dengan dilakukan pertanggungjawaban tersebut kami selaku krama jadi mengetahui berapa jumlah pinjaman yang tersebar di krama, jumlah jinah yang diperoleh dari cecingkreman tiap bulannya. Itu 
semua diumumkan secara transparan dan kami selaku krama dapat melihat secara detai mengenai pencatatanya di buku Ceceingkreman dik"

Berdasarkan pernyataan diatas dapat disimpulkan bahwa bentuk pertanggungjawabannya secara lisan dan tertulis untuk masing-masing anggota sekaa oleh bendahara dalam malam akhir piodalan.

\section{Simpulan dan Saran}

Berdasarkan hasil penelitian yang telah dibahsa sebelumnya dapat disimpulkan bahwa (1) Cecingkreman di Dadia Pasek Gelgel Terbentuk sebagai sarana untuk membantu masyarakat dalam memenuhi kebuthan yang dimiliki dengan memberikan pinjaman dana yang mana pemberian dana ini diberikan ke krama berasal dari penggalangan dana kolektif dadia yang menyebabkan terjadinya penggemukan dana, dengan dilaksanakan cecingkreman ini selain memberikan feedback bagi dadia dalam bentuk bunga juga memiliki manfaat tersendiri bagi krama. Pembentukan cecingkreman ini juga memiliki tujuan untuk menjaga solidaritas yang ada di krama dadia. (2) Mekanisme sistem pengelolaan cecingkreman di Dadia Pasek Gelgel Tabang Desa Bebetin dilakukan dengan empat tahp diantaranya yaitu tahap perencanaan pada tahap ini dadia membentuk cecingkreman, stahap pelaksanaan dadia membuat kebijakan mengenai cecingkreman dengan prosedur yang telah disepakati, tahap penatausahaan para pengelola melakukan pencatatan mengenai cecingkreman yang dijalankan dan tahap terkakhir pertanggungjawaban yang mana dalam hal ini para pengelola melakukan pertanggungjawaban kepada kram dadia atas pengelolaan cecingkreman dengan menyampaikan keseluruhan transaksi yang terjadi pada saat dilakukannya cecingkreman, pertanggungjawaban ini dilakukan pada saat diadakannya sangkepan ataupun paruman dadia.

Adapun saran yang dapat disampaikan bagi Pengelola Dadia Pasek Gelgel Tabang Desa Bebetin yaitu pada saat melakukan paruman mengenai pertanggungjawaban cecingkreman sebaiknya membuatkan output mengenai keseluruhan pengelolaan cecingkreman dan juga memberin print copy kepada krama dadia agar keseluruhan krama dadia mengetahui secara real mengenai pengelolaan cecingkreman yang telah dilakukan, sedangkan bagi Peneliti Selanjutnya diharapkan dapat menambahkan kajian-kajian teori yang mampu mendukung penelitian yang berkaitan dengan pengelolaan cecingkreman karena penelitian yang dilakukan ini disadari masih banyak kekurangan.

\section{Daftar Rujukan}

Bastian, I. (2010). Akuntansi Sektor Publik Suatu Pengantar Edisi Ketiga. Penerbit: Erlangga.

Gunawijaya, R. (2017). Kebutuhan Manusia Dalam Pandangan Ekonomi Kapitalis Dan Ekonomi Islam. Al-Maslahah Jurnal IImu Syariah. https://doi.org/10.24260/almaslahah.v13i1.921

Krina, L. L. (2003). Indikator \& Alat Ukur Prinsip Akuntabilitas, Transparansi \& Partisipasi. Sekretariat Good Public Governance BPPN.

Mankiw, N. G. (2007). Makro Ekonomi Edisi ke-6. Penerbit : Erlangga.

Megawati, L. K. S. (2014). Analisis Pengelolaan Keuangan Berbasis Sistem Urunan Aci Pada Dadia Batan Bingin Dusun Muntigunung Desa Tianyar Barat Kecamatan Kubu Kabupaten Karangasem. Universitas Pendidikan Ganesha.

Nasution, Z. (2009). Solidaritas Sosial Masyarakat Transisi. Penerbit : UMM Press.

Nurdamasih, K. (2019). Transparansi dan Akuntabilitas Pengelolaan Keuangan Sistem 
Pemberian Kredit Mutranin Pada Dadia Tangkas Kori Agung Desa Pekraman Bila Bajang Kecamatan Kubutambahan. Universitas Pendidikan Ganesha.

Pandu, G. A. (2016). Transparansi dan Akuntabilitas Pengelolaan Dana Dadia yang Dilandasi Konsep Budaya Lokal Tri Hita Karana (Studi Kasus Dadia Tangkas Kori Agung di Desa Pekraman Tegallenge). Universitas Pendidikan Ganesha.

Riani, K. Y. (2017). Analisis Transparansi dan Akuntabilitas Pengelolaan Dana di Tingkat Dadia (Studi Kasus Pada Dadia Pasek Gelgel Dusun Gambang Desa Pekraman Alapsari). Universitas Pendidikan Ganesha.

Shohib, M. (2013). Sikap Terhadap Uang dan Perilaku Berhutang. Jurnal: IImiah Psikologi Terapan. https://doi.org/10.1017/CBO9781107415324.004

Sugiyono. 2016. metode penelitian kuantitatif, kualitatif,dan $R \& D$, Alfabeta, cv. 